\title{
Impact of Pre-Speaking Activities on Iranian Intermediate EFL Learners' Oral Performance
}

\section{Dina Dabiri ${ }^{1} \&$ Abbas Pourhosein Gilakjani ${ }^{1 *}$}

\footnotetext{
* Correspondence:

abbas.pourhossein@yahoo.com

1. Department of English Language

Translation, Lahijan Branch, Islamic

Azad University, Lahijan, Iran
}

Received: 4 April 2019

Revision: 30 May 2019

Accepted: 17 June 2019

Published online: 20 June 2019

\section{Abstract}

This study aimed to investigate the impact of pre-speaking activities on Iranian intermediate English as a Foreign Language (EFL) learners' oral performance. The study followed a quasi-experimental design in which subjects of the study were non-randomly selected. Oxford Placement Test (OPT) was used to select 100 intermediate EFL learners as the main sample. Then they were divided randomly into two experimental and control groups. Prior to the treatment, participants of both groups were given a pretest of speaking to ensure their speaking ability. After a treatment of pre-speaking activities to members of the experimental group, a posttest of speaking was administered to seek the effect of it. A t-test was run to examine the difference between the mean scores of each group in posttests. It was found that there was a statistically significant difference between the experimental and the control group. That is, the experimental group outperformed the control group in oral performance.

Keywords: EFL Learners, speaking, pre-speaking activities, oral performance 


\section{Introduction}

One of the challenges in educational settings is to involve learners in meaningful speaking activities so that they can use the language actively. Learners' low level of vocabulary and pronunciation are the key factors that prevent them from speaking English. In addition, anxiety and fear many learners experience using the language orally can play their role in the situation (Ansari, 2015; Rivera \& Mazak, 2015; Soto-Santiago, Ramírez Ortiz, \& Artunduaga Cuéllar, 2018; Tsiplakides, 2009). Speaking English is usually the first step to learn a second or foreign language which is preferable than the other three English language skills (listening, reading, and writing). According to Tutyandari (2005), speaking is a complex task; so many students in an EFL speaking class have not the courage to speak. Thus, many of the students feel anxious in a speaking class, and some are likely to keep silent. Speaking is not an easy task, its mastery claims a lot of experience and practice.

Luoma (2004) argues that it is difficult to develop competence in speaking. For this reason, all EFL learners believe that speaking has a significant role in language learning. It promotes communicative efficiency; teachers want students to be able to use language fluently and correctly as much as possible. Learners as well give the speaking skill priority in their learning because it is the active use of language to express meaning. Although EFL learners spend long years studying English, they cannot easily speak it (Thornbury, 2007). One of the main difficulties is that speaking usually takes place spontaneously in real time, which means that planning and production overlap. If too much attention is paid to planning, production suffers, and the effect is a loss of fluency, on the other hand, if the speaker's attention is directed solely on production, it is likely that accuracy will suffer. In order to free up attention, therefore, the speaker needs to have achieved a degree of automaticity in both planning and production.

According to Aliakbari and Jamalvandi (2010), being capable to communicate orally with each other and using effectively the target language is nowadays of the utmost importance, up to the point where learners who are not able to be fluent in using a foreign language cannot be considered effective language users. Any gap in commutation results in misunderstandings and problems. Derakhshan et al. (2016) stated that one of the obstacles to learning speaking is a contradiction between class materials and courses so that most of the teachers do not facilitate situations for real practice in speaking. Besides, the teacher should take into account the learners' interests and needs. Learners should take part in oral activities to exchange spontaneously their thought in second language speaking. Confidence and enthusiasm are critical factors in oral language development, and because much oral language is immediate, it involves taking risks.

Another feature of a successful speaking activity pointed by Brown (2001) is even participation. All students should get a chance to speak; moreover, contributions ought to be fairly evenly distributed. Therefore, teachers' task is to strive towards engaging the less active learners and make sure that all students are involved in an equal way. The last important principle mentioned by Ur (1996), is the acceptable level of the language used. A teacher can achieve it by selecting activities whose language level is similar to students' linguistic level. Such oral tasks empower students and give learners the possibility to clearly express their ideas and opinions through fluent speech.

Efrizal (2012) Nasiri and Pourhosein Gilakjani (2016) stated that speaking is very important for the learners' interaction where they speak everywhere and every day. Speaking is the way of communicating ideas orally. If teachers want to urge learners to communicate in English, they should use the language in real communication. Fink (2003) and Ramírez Ortiz and Artunduaga Cuéllar (2018) emphasized the significance of encouraging learners to connect the knowledge received in classes with their lives so that this information can be used in new situations. Learners are often reluctant to participate in oral activities because they do not see any relevance between these activities and their daily lives; consequently, the primary aim of this study was to investigate the impact of prespeaking activities on the oral performance of Iranian EFL learners. Given the importance of engaging learners in active learning, pre-speaking activities were thought of as an effective alternative to bring learners' reality to the classroom to improve oral performance.

\subsection{Statement of the Problem}

Since English becomes the most essential language in the world almost all the people from many different countries around the world use it to communicate. The area of English has always become a special interest. It's because of the importance of English in any scope of our lives. What makes speaking difficult is just because of the English language. It is a foreign language and the use of it is very seldom. We can see easily many things in our life using English in the written form and it does not need to be read aloud, so we do not need to be embarrassed. Littlewood (2007) asserts that a foreign language classroom can create inhibitions and anxiety easily. When students try to say things in a foreign language in the classroom, they are often inhibited. They are worried about making mistakes, fearful of criticism or losing face. They are shy of the attention that their speech attracts. Communication skills are regarded as one of the important skills that learners should develop. Anxiety and fear can impact learners' ability to communicate well in 
interpersonal and group discussions. These feelings affect learners' attitudes towards involvement in communication situations. Learners feel embarrassed to speak in front of their friends and teachers because they afraid of making mistakes (Abdul Rahman \& Maarof, 2018).

Learners often complain that they cannot think of anything to say and they have no motivation to express themselves. Learners have nothing to express maybe because the teacher had chosen a topic which is not suitable for him or about which he knows very little. It is difficult for many students to respond when the teachers ask them to say something in a foreign language because they might have little ideas about what to say, which vocabulary to use, or how to use the grammar correctly (Baker \& Westrup, 2003). Speaking is the second skill and has an important role in communication. Speaking is a part of daily life that everyone should develop in subtle and detailed language. While young language learners acquire foreign language easier and faster, adults are eager in achieving new language and developing language abilities. It seems that adults fail to achieve native-like proficiency because of fossilization; they have problems with prosodic features like intonation, stress, and rhythm (Renandya, 2002).

Speaking is very significant in second language learning. Despite its importance, speaking has been ignored in schools and universities due to various reasons such as emphasis on grammar and unfavorable teacher-student proportions (Clifford, 1987; Leong \& Ahmadi, 2017). Opportunities for speaking require much structure and planning. Learners often think that the ability to communicate is to know about grammar, but it is also not at the beginning of the nineteenth century that the systematic role of teaching was about grammar and then the first method appeared which was called Grammar Translation Method. It was based on grammar and did not help students' speaking ability. After a long time, the evidence showed that listening and reading can improve speaking skill because reading can affect both fluency and accuracy of expression in their speaking (Celce-Murica, 2001). Learning to speak needs a lot of practice; besides, learners should use short dialogue and questions and answers.

Another problem in speaking class is that participation is low or uneven. In a large group, each student will have very little talking time because only one participant can talk at a time so that the others can hear him/her. There is a tendency of some learners to dominate while others speak very little or not at all. The emphasis is not only on linguistic competence of the language learners but also on the development of their communicative ability. The students often find some problems in learning speaking skill. Some factors like interest, the material, and the media among others including the technique in teaching English can cause problems for the students. Based on Dolati and Mikaili (2011), most foreign language learners in Iran face difficulty in speaking skill.

Some experts hold that EFL students' speaking skills might be affected by a multitude of factors. Al Hosni (2014) states that EFL students may face numerous problems in the way of developing their speaking skills regardless of their linguistic knowledge. These problems can be traced back to their minimal direct exposure to the target language. Aleksandrzak (2011) also believes that the source of speaking skills problems in the EFL context is the insufficient speaking varieties and opportunities in the EFL classrooms compared to multitude varieties and genres in real-life situations. Hojati and Afghari (2013) maintain that speaking skills are under the influence of a number of linguistic and non-linguistic factors such as grammar, vocabulary, pragmatic variables, affective factors, and so forth which, when combined, compound the problems of speaking skills.

Soureshjani and Riahipour (2012) conducted an inquiry into 215 Iranian EFL students' and EFL instructors' attitudes regarding speaking skills problems. The findings of the study revealed that students believed that the lack of teaching equipment, class facilities, and instructors were among problem-causing factors for the development of their speaking skills while instructors believed that the instructors, the amount of time allocated for speaking classes, and the classroom atmosphere were among the problematic factors for speaking skills. As Ohato (2005) mentioned that Iranian students, after studying English even at advanced levels, face problems to express themselves. One reason may be that English is taught formally as a foreign language and only grammar and translation have been focused upon at schools. Therefore, many people have been complaining that Iranian students cannot speak English despite studying English for six years or more. Some techniques can be employed to improve the students' speaking ability. Therefore, different ways of teaching speaking should be acquired and practiced for effective speaking in an EFL context in Iran.

\subsection{Research Question}

The following question was proposed based on the purpose of this study:

Do pre-speaking activities have any impact on Iranian intermediate EFL learners' oral performance?

\subsection{Hypothesis of the Study}

To fulfill the aim of the study practically through the above-mentioned research question, the following null hypothesis was considered: 
Pre-speaking activities do not have any impact on Iranian intermediate EFL learners' oral performance.

\section{Review of the Literature}

\subsection{Definition of Speaking Skill}

Speaking skill has been defined in different ways. According to Bashir, Azem, and Dogar (2011) and Ngan (2013), speaking is a productive skill in the oral mode. It is more complicated than it seems at the first and includes more than just pronouncing words. Hornby (1995) and Ngan (2013) defined speaking as the skill that the students will be judged upon in the real-life situations. It is an important part of everyday interaction and the first impression of an individual is based on his/her ability to speak fluently and comprehensively. In addition, Grognet (1997) and Ngan (2013) defined it as one of the skills that students should master in learning English. It is an important tool for communication.

Harmer (2001) stated that speaking skill has two major categories: accuracy and fluency. Accuracy is the correct use of vocabulary, grammar, and pronunciation practiced through controlled and guided activities. Fluency is the ability to keep going when speaking spontaneously. Furthermore, Bryne (1986) defined accuracy as the use of correct forms where utterances do not involve errors impacting the phonological, syntactic, and semantic or discourse features of a language and fluency as the ability to get across communicative intent without too much hesitation and too many pauses to cause obstacles or a breakdown in communication. In addition, Brown (1994), Burns and Joyce (1997), Leong and Ahmadi (2017), and Fouladi Nashta and Rahimy (2018) defined speaking as an interactive process of making meaning that involves producing, receiving, and processing information.

\subsection{Stages of Speaking}

Three main stages of a speaking lesson are: pre-speaking, while-speaking, and post-speaking (Ngan, 2013). The first stage is pre-speaking stage (presentation stage). This stage prepares students for getting them to think about the topic or situation before they speak about it. Pre-speaking activities involve discussion or brainstorming, where students collect all their ideas on the topic; vocabulary preparation, where the teacher pre-teaches key vocabulary to help comprehension; prediction, where students guess what they may learn about. A good pre-speaking activity also includes integrating skills, maybe listening and sometimes reading. This stage should be short, about 10 minutes equivalent the presentation stage of a grammar lesson, but giving enough time for students to assimilate to what they are going to speak. Warm-up activities may be involved in this stage. The teacher's role is to get students think about what they are going to speak before they speak. The teacher should set up the pre-task and his/her clear instructions are needed (Ngan, 2013).

Pre-speaking begins before students actually speak. Students' experiences, observations, and interactions inside and outside of the classroom have an impact upon what they say and how they say it. Thought and reflection are parts of pre-speaking activities. These activities help the learners to plan and organize for speaking. Some purposes for prespeaking are that students generate and explore ideas for speaking topics through activities. Profile course offers a number of pre-speaking activities such as constructing thought webs and graphic organizer, reading something relevant to the topic, listening to a speaker, jotting down ideas, reflecting upon personal experience and reviewing vocabulary necessary for the topic. Photographs, pictures, and cartoons are visual stimuli that teachers use them as pre-speaking activities. Learners can plan their speech in terms of words, phrases, and ideas in pre-speaking stage. This can be achieved by requiring learners to write notes on a sheet of paper to ensure that they did engage in planning and that there is evidence of this planning to be removed at the end of the planning period. Ellis (2005) call this kind of planning as "strategic planning." When the learners have the opportunity to plan in advance, they can organize the propositional content and this results in greater fluency during actual task performance. It also helps them handle communicative strains and pressures (Ryo, 2005).

When the learners are taught through pre-speaking planning, they can plan automatically in the long run (Ellis, 2005). Through planning, learners free their attention and helps them focus on accuracy and complexity rather than relying only on ready-made lexical phrases to cope with real time demands (Ellis, 2003). Online noticing and hypothesis testing are fostered by pre-speaking activities (Robinson, 2003). The second stage is while-speaking stage (practice stage). This stage is the time for students to practice speaking. The teacher does not have to do a lot of things because students will be working on the while activities individually or in pairs, in groups. When working on the activities, they may have some problems due to a lack of language variety; thus, during this stage, the teacher monitors and helps weaker students with their problems in completing while activities instead. The teacher evaluates how well students have completed the activities and whether they are ready to go to the next stage or not. Communicative activities are used in this stage for the aim of helping students practice speaking skill. They can be a role play, a game, or a discussion (Ngan, 2013). 
The third stage is post-speaking stage (personalization stage). This stage helps students take the information or whatever they have produced in the previous stage and do something meaningful with it. The post task is "an information transfer" - a production kind of exercise where they respond to what they have just learnt. They respond in the way that relating what they have learnt to their own experience. Writing is a very suitable skill for this stage. If students perform a questionnaire on their friends in the while task, they may write up the results in a short paragraph (Ngan, 2013).

\subsection{Previous Findings on the Impact of Pre-Speaking Activities on Learners' Oral Performance}

A lot of researchers have carried out studies to find out how using pre-speaking activities can have a great effect on learners' oral performance. Harmer (2001) declared that it is necessary for teachers to develop speaking through interesting and relevant activities, in a contextualized manner, and related with the communicative necessities of the given population. In this way, communication will occur in the classes and students will have the opportunity to use the target language in real life situations. Protheroe (2004) conducted a study about speaking tasks and students' personality. The findings indicated that using contextualized materials as one of the speaking activities promoted oral participation among introverted students. Protheroe (2004) continued that the variation of materials and the use of contextualized topics makes the students feel confident and motivated and they start to get involved in the activities proposed by the teacher.

Kayi (2009) asserted that when a person is learning a foreign language, the speaking skill becomes necessary for the achievement and development of the tasks that are set in the target language. Therefore, speaking is an important skill and its role is related to the future academic development of students and provide principles for language teachers. In the same way, Boonkit (2010) declared that speaking is one of the important skills to be developed as a means of effective communication in language learning contexts. In the English as a Foreign Language (EFL) pedagogy environment, how to increase speaking competence and confidence for undergraduate students tends to be a crucial question among instructors. He carried out a qualitative research design to examine learners' oral production. The results obtained from this research revealed that confidence, creativity of topics, and speaking competence were the key aspects of improvement when speaking to the audience.

Another study was performed by Pattanpichet (2011) to examine the impacts of using cooperative language in promoting students' speaking achievement. Thirty five students participated in this research. To investigate the students' views on using cooperative language, they were asked to complete a student diary after finishing each task, fill in a four scale-rating questionnaire, and join a semi-structured interview at the end of the course. Then the collected data were analyzed. The results indicated the improvement of the students' speaking performance and positive feedback from the students on using collaborative learning activities.

Moreover, Ramírez Ortiz and Artunduaga Cuéllar (2018) conducted a study on the impact of authentic tasks in fostering oral production. The study presented the findings of a qualitative action research investigating the effect of authentic tasks in oral production with a group of tenth graders in a public high school in the south of Colombia. The results of this study revealed the positive effect of authentic activities on oral production and teachers are recommended to use authentic tasks in the classroom to involve students in meaningful learning to improve oral production. In addition, Bocanegra Bonilla and Ramirez Valencia (2018) carried out a study to examine the impact of a set of speaking activities on improving learners' oral performance. The participants involve fourth graders of a public school in Colombia, who had low oral performance in spoken language. The results of the study showed that the proposed speaking activities were comprehensible for the learners and suitable for their proficiency level. The other result was that a lot of learners were comfortable speaking during the activities since they were familiar with watching cartoons, thus being at ease with certain topics can help learners exchange ideas in class.

A number of studies have been carried out in Iran to examine the effect of pre-speaking activities on EFL learners' oral performance. Farooqui (2007) interviewed five English teachers in private universities, and he collected their perception of students' problem in speaking and the reasons for the problem. Three of them said that students do better in reading and writing, but they do poorly in speaking. They feel shy and do not want to speak in front of the classroom. In another investigation, Aliakbari (2010) investigated the impact of role play on fostering EFL learners' speaking ability. He found that role-play technique directed by Task Based Language Teaching (TBLT) is effective in helping learners to upgrade their oral ability, at least at the Iranian EFL context. Therefore, it is recommended that this activity along with TBLT guidelines be included among various activities in courses intended for improving learners' oral skills.

Likewise, Rahimy and Safarpour (2012) investigated the effect of role-play as a classroom activity on Iranian EFL learners' speaking ability. This study tried to determine whether or not using role-play activities in speaking 
classrooms might enhance a more acceptable speaking ability in Iranian EFL learners at the intermediate level. The results of the present study enunciated that role-playing seems to provide a sort of enjoyable environment for the learners to flourish in. This reason leads to better attention in learning and stimulate them to participate in role-play activities. In role-play activities, students take a new identity and learn to use a foreign language for every day communication.

By the same token, Asaei and Rahimy (2012) investigated the effect of using audio texts as a classroom activity in teaching English speaking skill on Iranian EFL learners' speaking ability. 60 junior undergraduate translator trainees participated in the experiment of this study. They were randomly selected from among a population of translator trainees via an Oxford Placement Test (OPT) test score of at least one standard deviation below the mean. They were then divided into two groups of 30 and were randomly assigned to an experimental and a control group. A pre-test of English speaking was administered to both groups, then, they were taught speaking for 10 sessions but with different methodologies: the experimental group received a treatment of audio texts while the control group received a placebo. The results indicated that the Iranian EFL learners in the experimental group received higher speaking scores after being treated with 10 sessions of audio texts.

Furthermore, Shabani (2013) explored the effect of background knowledge or topic familiarity on speaking ability of Iranian students. The study was performed in a pre-university class including 10 students. A quasi-experimental design was employed. The findings of this study indicated that when the subjects could get familiarity with the subject matters, they became knowledgeable about the topics and could easily talk about them in their classes. He found that background knowledge of the subjects has a positive effect on their speaking ability: the more they have background knowledge about a topic, that is, the more they become familiar with a topic, the more they can talk about it, and the more their speaking ability improves. Similarly, Nouralian et al. (2013) conducted a study to investigate the impact of psychodrama (role-play) on Iranian Intermediate EFL learners' speaking ability. For this purpose, 100 learners of English at Iran Language Institute (ILI) participated in this study. They found that the use of psychodrama (role-play) technique improved speaking ability of EFL students. The study also revealed that the students were extremely satisfied with this technique. It enabled the students to formulate their turns and gave them a better opportunity to improve their English speaking.

Additionally, Nezhadmehr and Shahidy (2014) examined the impact of interaction strategy training on the speaking skill of Iranian Intermediate EFL learners. The present work investigated if classroom interaction could be a best pedagogical strategy to develop the Iranian Intermediate EFL learners' speaking skill. Results indicated that there is a significant difference in the participants' use of interaction strategies. After the strategy training, participants employed the interaction strategy of "appeal for assistance" most often, and they also used this strategy significantly more often in the post-test than in the pre-test. Learners showed the considerable awareness about the impact of classroom interaction on developing their speaking skill through interaction strategy training which helped them to understand the spoken language accurately and then use it appropriately.

Finally, Zare Behtash, Saed, and Zare Behtash (2017) performed a study on the impact of role-playing tasks on the speaking ability of Iranian pre-intermediate English for Specific Purposes (ESP) learners. The researchers investigated the learners' speaking ability in two groups: the experimental group and the control group. Twenty four male and female ESP learners at pre-intermediate level were chosen after taking a pre-test. Then, they were randomly assigned into two groups. In the experimental group, role-playing tasks were used for teaching conversation, but the control group was exposed to the conventional method of teaching speaking. After 18 sessions of treatment, a post-test was conducted to measure the learners' speaking ability. The data were collected through two Longman Placement Test (2004) and the semi-structured interviews. Then the data were analyzed through two independent and paired sample t-tests. The findings indicated that the participants in the experimental group showed a significantly better performance in the post-test. It was also concluded that the treatment provided for the experimental group had a positive impact on the learners' speaking skill.

\section{Methodology}

In this section, the research methodology including design of the study, participants, materials, procedure, and methods of data analysis have been discussed in details.

\subsection{The Design of the Study}

The current study followed a quasi-experimental design in which subjects of the study were non-randomly selected, were made homogeneous, and then their intact classes were randomly assigned into control and experimental groups in order to investigate the research question of the study. The reason to call the design of this study as quasiexperimental one is the lack of randomization which is one of the main principles of true experimental method of 
research. The experimental group received pre-speaking activities treatment, however, the control group followed the traditional way of teaching speaking. So, the schematic representation of the design is as follows:

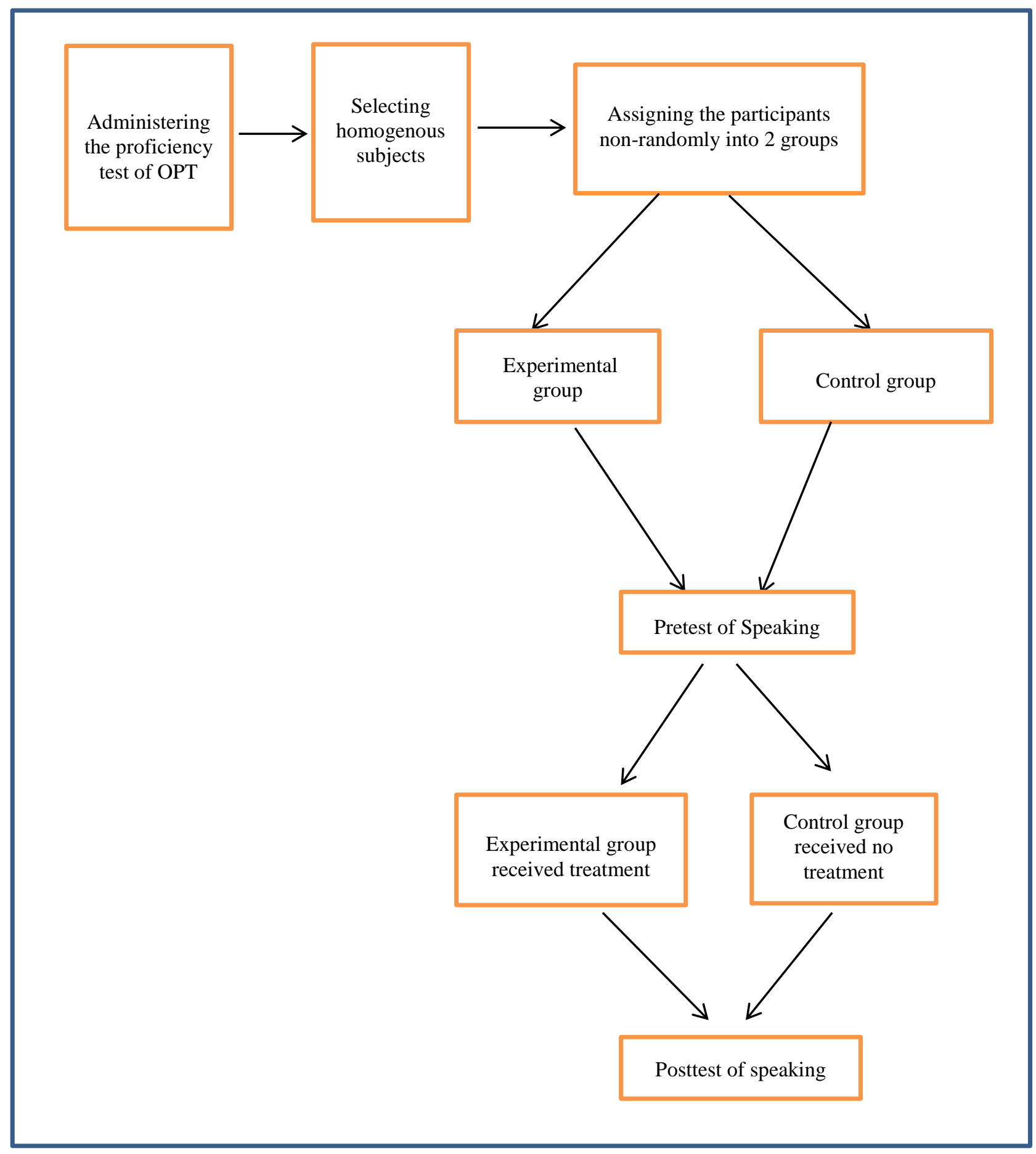

Figure 1. Design of the Study

\subsection{Participants}

The main subjects of the study were 100 Iranian female learners who were selected randomly among 150 intermediate learners of a private institute in Lahijan, with the age range of 15-20. The subjects were learning English in "Mohajer" 
language institute in Lahijan. The participants were divided into two groups, each consisting of 50 (control) and 50 (experimental) students. They were in the same proficiency level as measured by a Quick Placement Test (QPT) with the criteria of at least 1 standard deviation below to 1 standard deviation over the mean.

\subsection{Materials and Procedures}

In order to homogenize the participants, QPT was used. It was administered to 150 intermediate EFL learners. After analyzing the results, 100 subjects were assigned into two groups. Prior to the study, an interview was piloted with a reliability index of 0.79 . It was used to measure speaking ability both as a pre- and post-test. The allotted time to test administration was 55 minutes. The experimental group received pre-speaking activities as treatment. Each session before speaking, teacher introduced the topic (talks a bit about it) and aroused interest. The teacher uttered the title of the presentation (or that day's topic) and led a small discussion about it. Then, the teacher provided some language material to use in pre-speaking (a grammar topic that may be useful while talking about a specific topic).

After that, the teacher questioned the students to assess student's knowledge and familiarity with the topic. The teacher asked a question or gave another reason before talking about a topic. The teacher focused on some speaking strategies (like starting a discussion or ending a speech) before the discussion. The teacher brought some visual materials to the class. The teacher focused on the new vocabulary that will be necessary to understand a speech. The teacher sat scene that was helpful for students to imagine the setting related with the topic. Sometimes, the teacher told a joke, an anecdote, or a real life event to introduce the topic. Students watched a related movie, a cartoon, or a documentary before talking about the topic.

The above-mentioned items also indicated that the teacher should know what s/he is doing with the teaching materials and s/he has control over them. The control group received no treatment and followed the traditional way of teaching speaking. After ten sessions, the post-test of speaking skill was administered to both groups. To get rid of subjectivity and personal bias, the students' responses were evaluated in term of grammar, vocabulary, comprehension, fluency, and pronunciation by using the scale suggested by Brown (2000), each element scores from 5-1 marks.

\subsubsection{Material and Procedure for the Proficiency Test of the Study}

A commonly used placement test which is chosen by many language institutes to assess students' readiness and English abilities is the QPT. Its popularity can be attributed to test qualities such as being economical, easy to administer, and easy to score. QPT has also been ethically tested; that is, no ethical offence exists in it. Placement test is an essential part of a language teaching process, because there is always a broad range of competences among students who enroll in English programs as a result of their differences in linguistic aptitude, ability, motivation, and quality of instruction received. To make sure that these differences are taken into consideration, the entry level of all students should be recognized so that they may be placed in their appropriate classes (Armstrong, 2000).

Therefore, QPT was administered to 150 EFL learners in order to select a homogeneous sample. The test comprised different types of items including both the components and skills of the English language. This placement test included three parts. Part one and two consist of 60 multiple-choice question items, and in part three, they were supposed to write a writing.

Part One (Questions 1 - 40)

Part Two (Questions $41-60)$

Part Three (Writing section)

\subsubsection{Material and Procedure for the Pre-test and Post-test of the Study}

The researchers gave the pre-test to the students. The pre-test is in oral test form. The test consists of 10 questions. The scores are taken in five criteria, which are the scores of pronunciation, grammar, vocabulary, fluency, and comprehension. The researchers gave the post-test to the students. The test is similar to the pre-test. However, the post-test was given after the treatment. The scores are taken in five criteria, which are the scores of pronunciation, grammar, vocabulary, fluency, and comprehension. An interview was used to measure speaking ability both as a preand post-test. According to Farhady et al. (2003), the oral interview is the most valid test of speaking that should follow some guidelines to validate itself. Each interview should be carefully structured. Interviews should be natural and realistic to the extent possible; yet it is not desirable to conduct them spontaneously.

- To obtain dependable results, it is necessary to utilize the services of at least two raters.

- At the beginning of the interview, the candidate should be put at ease by being asked simple questions.

- The decision to use a global or specific scoring system should be based on the purpose of the test.

- Each interview should be recorded to be scored later. 
- 2 examiners got the interview with the students to observe the effect of learner's selected textbooks.

Therefore, the researchers prepared an interview according to the mentioned criteria and used for testing speaking ability. The interview as a pre- and post-test was piloted with a reliability index of 0.79 and then was administered.

\subsection{Data Analysis}

The data in this study were collected through QPT which was administered to 150 EFL learners and based on its result, 100 learners were chosen at intermediate level. Prior to the study, an interview was piloted with a reliability index of 0.79. It was used to measure speaking ability both as a pre- and post-test. The data were analyzed by running an Independent Samples t-test between the post-test of the study. Paired-sample t-test was also run between the pre-test and post-test of the groups of the study.

\section{Findings}

This section discusses the details of the results of the current study. The results were presented in two main sections: first, the procedures whereby the data were analyzed as well as the main findings of this study were elaborated on; second, the resulting status of the hypothesis of the study, that is, their rejection or support was explained. Both sections take advantage of illustrations such as tables and figures in order to provide a more clear-cut image of what has been obtained.

The nature of the hypothesis of the study required that the obtained data be analyzed using the descriptive and the inferential statistical methods. On the one hand, the descriptive statistics were used for sorting, displaying, and describing the data. This included the calculation of simple statistical attributes such as the measures of central tendency including mean. On the other hand, the data were interpreted via applying the inferential statistics which consisted of calculating a paired samples t-test for showing the possible difference between the means of the posttests of the study. What follows represents the findings from analyzing the whole data of the current study.

\subsection{Descriptive Analysis of the Data}

Descriptive analysis of the obtained data in this study is presented in this section. The Statistical Package for the Social Sciences (SPSS) software was used to analyze the data. Table 1 is a brief description of descriptive analysis of QPT.

Table 1. Descriptive statistics for QPT

\begin{tabular}{cccccc}
\hline & group & $\mathrm{N}$ & Mean & Std. Deviation & Std. Error Mean \\
\hline QPT & Con & 50 & 43.44 & 3.308 & .468 \\
& Exp & 50 & 43.66 & 3.134 & .443 \\
\hline
\end{tabular}

QPT was administered to select a homogeneous sample. As shown in Table 1, the mean of control $(X=43.44)$ and experimental $(X=43.66)$ groups were very close. It indicates that the participants were homogenized and they were at the same English proficiency level. Table 2 is a brief description of descriptive analysis of the pre-test of speaking.

Table 2. Descriptive statistics for pre-test

\begin{tabular}{cccccr}
\hline & group & $\mathrm{N}$ & Mean & Std. Deviation & Std. Error Mean \\
\hline Pre-test & Con & 50 & 32.98 & 3.335 & .472 \\
& Exp & 50 & 33.04 & 4.106 & .581 \\
\hline
\end{tabular}

As is indicated in Table 2, the number of participants was (NExp=50; NCon=50). There were not any significant differences between the mean of control $(\mathrm{X}=32.98)$ and experimental groups (33.04). The SD for each experimental and control group was (SD Exp=.581, SD Con= .472). 
As shown in Table 3, the mean score for the experimental group $(M=36.44)$ is higher than that for the control group. Table 3 also shows that the scores were more heterogeneous in the post-test of the experimental group (SD Exp= .667, SD Cont $=.454)$. It can be claimed that the speaking of EFL learners who received pre-speaking activities are higher than those who received no treatment.

Table 3. Descriptive statistics for post-test of speaking

\begin{tabular}{lllccr}
\hline & group & $\mathrm{N}$ & Mean & Std. Deviation & Std. Error Mean \\
\hline \multirow{2}{*}{ Post-test } & Con & 50 & 33.26 & 3.212 & .454 \\
& Exp & 50 & 36.44 & 4.717 & .667 \\
\hline
\end{tabular}

In order to examine the effect of training, paired t-test was used. The results are shown in Table 4.

Table 4. Descriptive statistics of Paired Sample T-Test

\begin{tabular}{cccccc}
\hline & & Mean & N & Std. Deviation & Std. Error Mean \\
\hline \multirow{2}{*}{ Pair 1 } & con.post & 33.26 & 50 & 3.212 & .454 \\
& con.pre & 32.98 & 50 & 3.335 & .472 \\
Pair 2 & exp.post & 36.44 & 50 & 4.717 & .667 \\
& exp.pre & 33.04 & 50 & 4.106 & .581 \\
\hline
\end{tabular}

The results indicated that there is a difference between the pre- and post-test of speaking for the experimental group $(\mathrm{M}=36.44, \mathrm{SD}=.667)$. It can be concluded that there is a great difference between the speaking ability of the control and the experimental groups. This might be due to the use of pre-speaking activities that improved the performance of the participants in the experimental group.

\subsection{The Inferential Analysis of the Data}

This section focused on inferential analysis of the obtained data of this study that was calculated using SPSS. In order to homogenize the participants and make sure they were at the same English proficiency level, QPT was conducted. Their papers were scored; the Mean (M) and Standard Deviation (SD) were calculated. Results indicated that two groups were at the same English proficiency level $(\mathrm{Sig}=.734)$.

To investigate the impact of pre-speaking activities on Iranian intermediate EFL learners' oral performance, an independent samples t-test was conducted to compare the speaking scores for the experimental and the control groups in pre-test. There was no significant difference for the experimental group $(\mathrm{M}=.1000, \mathrm{SD}=.4454)$ and the control group $(\mathrm{M}=.1000, \mathrm{SD}=.4454 ; \mathrm{t}=.080, \mathrm{p}=.824$, two-tailed). This implies that the performance of the experimental and the control groups on the speaking test did not differ in the pre-test. The results are shown in Table 5. 
Table 5. Independent Samples t-test of the experimental and the control groups

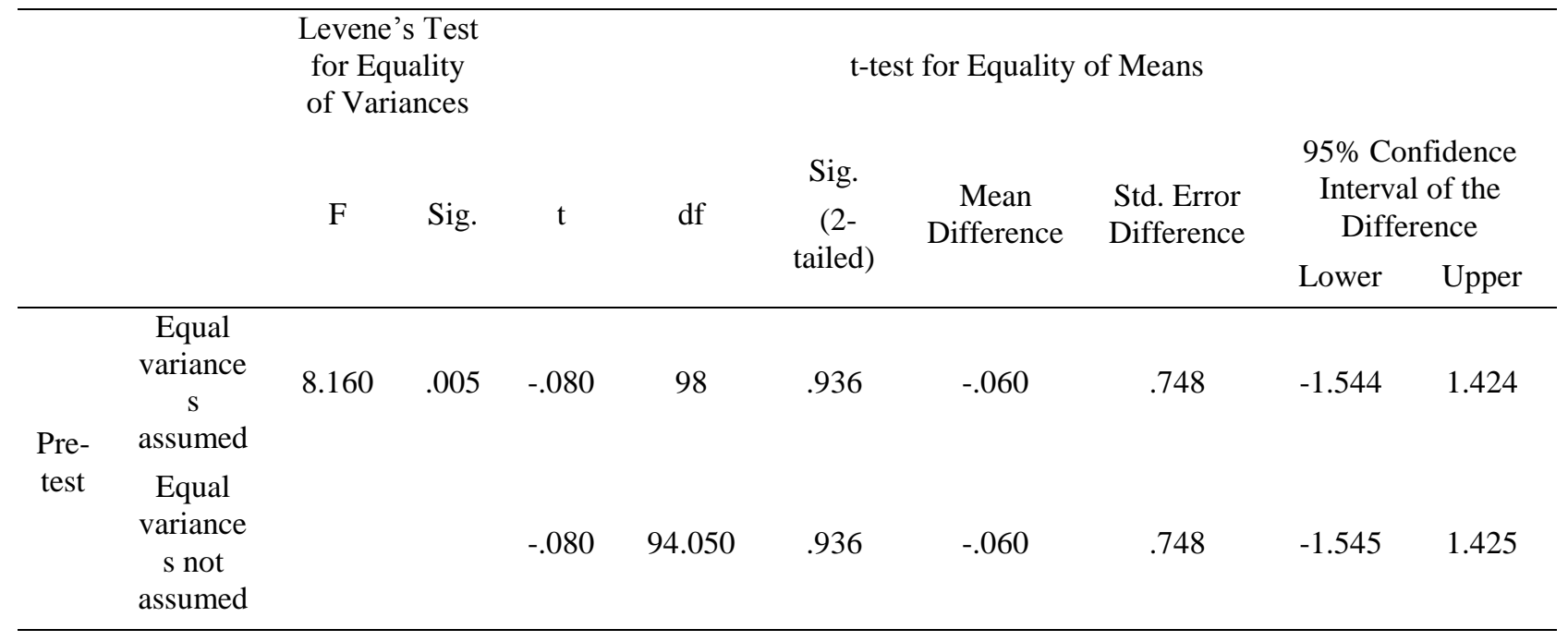

To investigate whether there was any significant difference between the experimental and the control groups in speaking post-test, an independent samples t-test was run. The participants' performances on the post-test of speaking are presented in Table 6.

Table 6. Comparing the experimental and the control groups on the speaking post-test

\begin{tabular}{|c|c|c|c|c|c|c|c|c|c|c|}
\hline & & $\begin{array}{r}\text { Leve } \\
\text { Test } \\
\text { Equal } \\
\text { Varia }\end{array}$ & $\begin{array}{l}\text { le's } \\
\text { for } \\
\text { ty of } \\
\text { nces }\end{array}$ & \multicolumn{7}{|c|}{ t-test for Equality of Means } \\
\hline & & \multirow[t]{2}{*}{$\mathrm{F}$} & \multirow[t]{2}{*}{ Sig. } & \multirow[t]{2}{*}{$\mathrm{t}$} & \multirow[t]{2}{*}{ df } & \multirow{2}{*}{$\begin{array}{l}\text { Sig. } \\
(2- \\
\text { tailed) }\end{array}$} & \multirow[t]{2}{*}{$\begin{array}{c}\text { Mean } \\
\text { Difference }\end{array}$} & \multirow[t]{2}{*}{$\begin{array}{l}\text { Std. Error } \\
\text { Difference }\end{array}$} & \multicolumn{2}{|c|}{$\begin{array}{l}\text { 95\% Confidence } \\
\text { Interval of the } \\
\text { Difference }\end{array}$} \\
\hline & & & & & & & & & Lower & Upper \\
\hline \multirow{2}{*}{$\begin{array}{l}\text { Post- } \\
\text { test }\end{array}$} & $\begin{array}{c}\text { Equal } \\
\text { variances } \\
\text { assumed }\end{array}$ & 6.866 & .010 & $\begin{array}{c}- \\
3.940\end{array}$ & 98 & .000 & -3.180 & .807 & -4.782 & -1.578 \\
\hline & $\begin{array}{c}\text { Equal } \\
\text { variances } \\
\text { not } \\
\text { assumed }\end{array}$ & & & $\begin{array}{c}- \\
3.940\end{array}$ & 86.403 & .000 & -3.180 & .807 & -4.784 & -1.576 \\
\hline
\end{tabular}

As shown in Table 6, the level of significance (sig=.000) indicates that pre-speaking activities have been effective in helping the language learners in the experimental group perform better in the speaking. Using pre-speaking activities improved the speaking ability of the participants in the experimental group. 
Table 7. Paired samples t-test, comparing pre- and post-tests of speaking scores of the experimental group and control group

\begin{tabular}{|c|c|c|c|c|c|c|c|c|c|}
\hline \multicolumn{10}{|c|}{ Paired Differences } \\
\hline & & \multirow[t]{2}{*}{ Mean } & \multirow[t]{2}{*}{$\begin{array}{c}\text { Std. } \\
\text { Deviation }\end{array}$} & \multirow{2}{*}{$\begin{array}{l}\text { Std. } \\
\text { Error } \\
\text { Mean }\end{array}$} & \multicolumn{2}{|c|}{$\begin{array}{l}\text { 95\% Confidence } \\
\text { Interval of the } \\
\text { Difference }\end{array}$} & \multirow[t]{2}{*}{$\mathrm{t}$} & \multirow[t]{2}{*}{ df } & \multirow[t]{2}{*}{$\begin{array}{c}\text { Sig. } \\
\text { (2-tailed) }\end{array}$} \\
\hline & & & & & Lower & Upper & & & \\
\hline Pair 1 & $\begin{array}{l}\text { con.post - } \\
\text { con.pre }\end{array}$ & .280 & 1.691 & .239 & -.201 & .761 & 1.171 & 49 & .247 \\
\hline Pair 2 & $\begin{array}{c}\text { exp.post - } \\
\text { exp.pre }\end{array}$ & 3.400 & 3.725 & .527 & 2.341 & 4.459 & 6.454 & 49 & .000 \\
\hline
\end{tabular}

As shown in Table 7, the mean score for the experimental group $(\mathrm{M}=3.400)$ is higher than that for the control group. Table 7 also shows that the scores were more heterogeneous in the post-test of the experimental group (SD Exp=3.725, SD Cont=3.725). The level of significance was calculated as to be 0.00 indicates that the speaking ability of both control and experimental groups differs greatly. This difference can be due to the use of pre-speaking activities by experimental group.

\subsection{Results of Hypothesis Testing}

In this section, the results of testing the hypothesis of the study have been presented and elaborated. In order to give a detailed analysis, attempts were made to take advantage of the results of the study as evidence to determine the rejection or support of the hypothesis. In addition, the rejection or support of the hypothesis is justified by explaining the consequences of such rejection or support, i.e. what would happen if the hypothesis of the current study is rejected or supported. Before analyzing the hypotheses, it will be repeated below:

H0: Pre-speaking activities do not have any impact on Iranian intermediate EFL learner's oral performance.

The hypothesis of this study which targeted the impact of pre-speaking activities on Iranian intermediate EFL learners' oral performance was rejected. Evidence from the findings of the study could help to verify the rejection. The results of the descriptive analysis of the study could be employed to confirm this analysis; accordingly, the mean scores of the speaking test in the pre-test and the post-test of the study were shown to be different in the experimental group as compared with the control group of the study. However, the degree of progress from the pre-test to the post-test of the study was not identical in both groups: the experimental group participants were more different in their scores of the post-test of speaking as compared with the scores of the control group of the study.

\section{Discussion}

This section discusses the findings of the study in light of the relevant literature. Following the discussion of findings, the pedagogical implications of the study are presented. The discussion seeks to investigate the impact of pre-speaking activities on Iranian intermediate EFL learners' oral performance. To be a successful instructor, it is a good idea for one to be armed with new techniques and strategies of teaching, to be able to understand the students' needs and potentialities, to identify the problems that the students might confront during the process of learning, to make an effort to offer practical suggestions based on his/her knowledge and experience, and finally try to implement the new techniques when needed in order to make teaching and learning more effective.

The present research cast light on one of the problematic aspects of EFL teaching/learning, namely speaking. Dakowska (2005) claims that speaking is now the most emphasized skill in the field of foreign language teaching, but unfortunately, it is also recognized as the most difficult one to develop in classroom conditions. The findings of this paper revealed that there is a great difference between the speaking ability of the control and the experimental groups. This was due to the usage of pre-speaking activities that improved the participants' performance in the experimental group. This finding is in line with the findings of Asaei and Rahimy's (2012) study who investigated the impact of using audio texts in teaching speaking skill on Iranian learners' speaking skill. 60 translator trainees were divided into two groups of 30 and were randomly assigned to an experimental group who received a treatment of audio texts and a control group who received a placebo. The findings of this research showed that Iranian learners in the experimental group received higher speaking scores than the control group.

The above finding also supports the finding of Zare Behtash, Saed, and Zare Behtash (2017) who carried a study on the effect of role-playing tasks on the Iranian learners' speaking skill. Learners were divided in two groups: the 
experimental group and the control group. The data were analyzed through two independent and paired sample t-tests. The results showed that the participants in the experimental group who used role-playing tasks for teaching conversation showed a significantly better performance in the post-test than the control group who was exposed to the conventional method of teaching speaking. The other result was that the treatment the experimental group received had a positive impact on the learners' speaking skill.

The findings of this study indicated that the mean scores of the speaking test in the pre-test and the post-test of the study were different in the experimental group as compared with the control group. That is, the degree of progress from the pre-test to the post-test of the study was not the same in both groups: the scores of the participants in the experimental group were higher than the scores in the control group of the post-test of speaking. This finding is in accordance with Nezhadmehr and Shahidy's (2014) study, investigating the effect of interaction strategy training on Iranian learners' speaking skill. The findings represented that there is a significant difference in the participants' use of interaction strategy and learners used this strategy significantly more in the post-test than in the pre-test. The finding also showed the positive effect of classroom interaction on developing learners' speaking skill which helped them to comprehend the spoken language correctly and use it properly.

One of the other findings of this research was that the use of pre-speaking activities increased learners' confidence in their oral production. This finding has been supported by the study of Skardal (2015) who investigated about the prespeaking activities and EFL learners' self-confidence. He found that pre-speaking activities improved the learners' self-confidence for speaking. The above finding is also in line with the findings of Protheroe (2004), Rahimy and Safarpour (2012), Shabani (2013), Bocanegra Bonilla and Ramirez Valencia (2018), expressing that pre-speaking activities seemed to be quite influential on the development of speaking proficiency and really enhanced learners' self-confidence in their oral production. The results of the present study indicated that working to increase learners' oral confidence will have positive effects on their oral activity and oral skills. Boonkit's (2010) research supports this idea, as learners' confidence is a significant factor which strengthens speakers' oral performance in front of a big audience. Using pre-speaking activities can be one of the effective ways of doing this.

For the sake of a successful learning process, students should be comfortable to speak and explore their own thinking. They should be encouraged to employ their ideas among classroom activities, to express themselves and achieve their goals. The speaking activities are one of the opportunities to practice the students' speaking skill which can highly support speaking fluency development in class. The goal is to have them learn and develop through speech and allow them to practice using all of the language they know in situations that resemble real settings. As Harmer (2001) reports since there were stimulation activities in the classroom for motivating the students, they increased the self-confidence of being of part in the classroom including answering the question, sharing the idea, and presentation. For that reason, the students may get discouraged in learning the language unless they get enough chances and activities to practice speaking skill in language classroom.

\section{Implications of the Study}

The most notable pedagogical implication which can be inferred from this study is that pre-speaking activities can improve the EFL learners' speaking ability. The implication of this study can be beneficial for teachers and learners in an EFL context. Different stakeholders in the field of language learning and teaching such as curriculum and material developers, course and syllabus designers, learners, teachers, and teacher trainers can gain positive advantages of the obtained results. Moreover, the findings of this study may be beneficial for curriculum developers and syllabus designers who provide teaching materials for Iranian English learners to pay more attention to learners' needs and include more pre-speaking activities in text books.

\section{Conclusion}

The aim of the study was to investigate the effect of pre-speaking activities on Iranian intermediate EFL learners' oral performance. The study consisted of the experimental group and the control group in which the experimental group was exposed to teaching speaking through pre-speaking activities. The researchers indicated that pre-speaking activities enhanced learners' speaking ability, as it was suggested and proved by other scholars who conducted the same study. The findings indicated that the use of pre-speaking activities does improve the learners' speaking ability. According to the findings of this study, it was concluded that pre-speaking activities have a positive impact on Iranian learners' oral production. The use of these activities promotes meaningful negotiation with learners about what they want to learn. By being actively involved in the learning process, learners can evaluate their own oral performance.

Regarding the aim of the study, it can be concluded that learners are more willing to speak in class as a result of being actively engaged in the use of activities. This occurs when learners are encouraged and supported by their teachers and gain confidence and start playing a more active role in pre-speaking activities. One of the important aspects this 
research dealt with is the kind of activities that facilitate learners' oral production. These activities help learners express and share their ideas meaningfully and freely. So it is important to keep constant communication with the learners to identify their desirable topics so they are involved and engaged in the whole learning process. Using prespeaking activities causes learners to feel more confident when presenting their oral production. This would be possible with continuous practice and permanent support of teachers. The results of this study revealed that students have difficulties in speaking, so the teachers should adopt new ways of teaching speaking. The researchers assume that if teachers have better knowledge of using pre-speaking in their teaching process, they can help learners improve their speaking ability.

\section{References}

Abdul Rahman, N. A.B., \& Maarof, N. (2018). The effect of role-play and simulation approach on nhancing ESL oral communication skills. International Journal of Research in English Education (IJREE), 3(3), 63-71. URL: http://ijreeonline.com/article-1-121-en.html doi: 10.29252/ijree.3.3.63

Aleksandrzak, M. (2011). Problems and challenges in teaching and learning speaking at advanced learning. Glottodidactica: An International Journal of Applied Linguistics, 37, 37-48. doi:10.14746/gl.2011.37.3 https://pressto.amu.edu.pl/index.php/gl/article/download/324/231

Al Hosni, S. (2014). Speaking difficulties encountered by young EFL learners. International Journal on Studies in English Language and Literature, 2(6), 22-30. fliphtml5.com/hidv/cpbq/basic

Aliakbari, M., \& Jamalvandi, B. (2010). The impact of role play on fostering EFL learners' speaking ability: A taskbased approach. Journal of Pan-Pacific Association of Applied Linguistics, 14(1), 15-29. https://files.eric.ed.gov/fulltext/EJ920501.pdf

Ansari, M. S. (2015). Speaking anxiety in ESL/EFL classrooms: A holistic approach and practical study. International Journal of Education Investigation, $38-46$. www.ijeionline.com/attachments/article/41/IJEIonline_Vol.2_No.4_2015-4-04.pdf

Armstrong, W. B. (2000). The association among students' success in courses, placement test scores, student background data and instructor grading practices. Journal of Research and Practice, 1(4), 681-695. https://doi.org/10.1080/10668920050140837

Baker, J., \& Westrup, H. (2003). Essential speaking skills: A handbook for English language teachers. London: Continuum.

Bashir, M., Azem, M., \& Dogar, A. H. (2011). Factors affecting students' English speaking skills. British Journal of Arts and Social Sciences. British Journal Publishing.

Bocanegra Bonilla, C., \& Ramirez Valencia, A. (2018). Speaking activities to foster students' oral performance at a public school. English Language Teaching, 11(8), 65-72. doi: 10.5539/elt.v11n8p65 URL: http://doi.org/10.5539/elt.v11n8p65

Boonkit, K. (2010). Enhancing the development of speaking skills for non-native speakers of English. Procedia Social and Behavioural Sciences, 2(2), 1305-1309. https://doi.org/10.1016/j.sbspro.2010.03.191

Brown, H. D. (2001). Teaching by principles: An interactive approach to language pedagogy. White Plains, NY: Longman.

Brown, S. (2000). Is rereading more effective than pre-reading? RELC Journal, 33(1), 91-100. https://doi.org/10.1177/003368820203300105

Byrne, D. (1986). Teaching oral English (6th edition). Longman Handbooks for Language Teachers. Harlow: Longman.

Celce-Murcia, M. (2001). Teaching English as a second or foreign language ( $3^{\text {rd }}$ ed.). United States: Heinle and Heinle.

Clifford, R. T. (1987). Language teaching in the Federal government: A personal perspective. Annals, AAPSS, 490.

Dakowska, M. (2005). Teaching English as a foreign language: A guide for professionals. Warszawa: Wydawnictwo Naukowe PWN.

Derakhshan, A., Khalili, N., \& Beheshti, F. (2016). Developing EFL learner's speaking ability, accuracy and fluency. English Language and Literature Studies, 6(2), 177-186. doi:10.5539/ells.v6n2p177 
Dolati, R., \& Mikaili, P. (2011). Opinions related to the main reasons on Iranian students' difficulties in spoken English proficiency. Australian Journal of Basic and Applied Sciences, 5(11), 1142-1148. eprints.umsu.ac.ir/1080/1/1142-1148.pdf

Efrizal, D. (2012). Improving students' speaking through communicative language teaching method at Mts Ja-alhaq, Sentot Ali Basa Islamic Boarding School of Bengkulu, Indonesia. International Journal of Humanities and Social Science, 2(20), 127-134.

Ellis, R. (2003). Methodological options in grammar teaching material. In E. Hinkel., \& S. Fotos (Eds.). New perspectives on grammar teaching in second language classrooms, (pp: 155-179). Mahwah: Lawrence Erlbaum Associates Publishers.

Ellis, R. (2005). Task-based language learning and teaching. Oxford: Oxford University Press.

Farhady, F., Jafarpur, A., \& Birjandi, P. (2003). Testing language skills from theory to practice. The Center for Studying and Compiling University Books in Humanities. (SAMT).

Farooqui, D. (2007). Developing speaking skills of adult learners in private universities in Bangladesh: problems and solutions. Australian Journal of Adult Learning, 47(1), 99-110. https://files.eric.ed.gov/fulltext/EJ797591.pdf

Fink, L. D. (2003). Creating significant learning experiences: An integrated approach to designing College courses. San Francisco: Jossey-Bass.

Fouladi Nashta, J., \& Rahimy, R. (2018). An investigation of the effectiveness dialogue shadowing technique (DST) on Iranian intermediate EFL learners' conversation ability. International Journal of Research in English Education, 3(2), 34-47. doi: 10.29252/ijree.3.2.34 URL: http://ijreeonline.com/article-1-98-en.html

Grognet, A. G. (1997). Definition of speaking skill. Providence: Jamastown Publisher.

Harmer, J. (2001). The practice of English language teaching. Longman.

Hojat, A., \& Afghari, A. (2013). An investigation of speaking-associated problems from students and instructors' perspectives. Iranian EFL Journal, 9(4), 9-31.

Hornby, G. (1995). Definition of speaking skill. New York Publisher.

Kayi, H. (2009). Teaching speaking: Activities to promote speaking in a second language. The Internet TESL Journal, XII(11), University of Nevada (Nevada, USA). iteslj.org/Techniques/Kayi-TeachingSpeaking.html

Leong, L. M., \& Ahmadi, S. M. (2017). An analysis of factors influencing learners' English speaking skill. International Journal of Research in English Education (IJREE), 2(1), 34-41. http://ijreeonline.com/article-138-en.html doi: 10.18869/acadpub.ijree.2.1.34

Littlewood, W. (2007). Communicative language teaching. Cambridge: Cambridge University Press.

Luoma, S. (2004). Assessing speaking. Cambridge: Cambridge University Press.

Nasiri, A., \& Pourhossein Gilakjani, A. (2016). A review of EFL learners' speaking skill and the strategies for improvement. Modern Journal of Language Teaching Methods (MJLTM), 6(9), 53-59. http://mjltm.org/article1-65-en.html doi: 10.26655/mjltm.2016.12.1

Nezhadmehr, M., \& Shahidy, H. (2014). The impact of interaction strategy training on the speaking skill of intermediate Iranian EFL learners. International Journal of Language Learning and Applied Linguistics World (IJLLALW), 6(4), 635-653.

Ngan, C. T. (2013). The application of communicative activities in English speaking classes of grade 11th students at Cao Lanh city high school. B.A. Thesis, Ministry Of Education and Training, Dongthap University, Foreign Languages Faculty.

Nouralian, R., Khodabandehlou, M., Jahandar, S., \& Najafi, M. (2013). The impact of psychodrama (role-play) on Iranian intermediate EFL learners' speaking ability. Indian Journal of Fundamental and Applied Life Sciences, $3(3), 675-682$.

Ohato, K. (2005). Potential sources of anxiety for Japanese learners of English: Preliminary case interviews with five Japanese college students in the U.S. TESL-EJ, 9(3), 1-25. https://eric.ed.gov/?id=EJ1065859

Pattanpichet, F. (2011). The effects of using collaborative learning to enhance students' English speaking achievement. Journal of College Teaching \& Learning, 8(11), 1-10. https://doi.org/10.19030/tlc.v8i11.6502 
Protheroe, N. (2004). Motivating reluctant learners. Retrieved from April 4, 2019: https://www.naesp.org/sites/default/files/resources/2/Principal/2004/S-Op46.pdf

Rahimy, R., \& Asaei, M. (2012). Audio texts and English speaking ability: Evidence from Iranian EFL learners. PartIII: Social Sciences \& Humanities, 3(2), 607-616. www.savap.org.pk/journals/ARInt./Vol.3(2)/2012(3.275).pdf

Rahimy, R., \& Safarpour, S. (2012). The effect of using role-play on Iranian EFL learners' speaking ability. Asian Journal of Social Sciences \& Humanities, 1(3), 50-59. www.ajssh.leenaluna.co.jp/AJSSHPDFs/Vol.1(3)/AJSSH2012(1.3-06).pdf

Ramírez Ortiz, S. M., \& Artunduaga Cuéllar, M. T. (2018). Authentic tasks to foster oral production among English as a foreign language learners. $H O W, 25(1), 51-68$. https://doi.org/10.19183/how.25.1.362

Renandya, W. A. (2002). Methodology in language teaching: An anthology of current practice. Cambridge: Cambridge University Press.

Robinson, P. (2003). The cognition hypothesis, task design, and adult task-based language learning. Second Language Studies, 21(2), 35-105. https://core.ac.uk/download/pdf/77238704.pdf

Ryo, N. (2005).On-line planning and focus-on-form in task-based learning. A paper presented at International Conference on Task-Based Language Teaching. September 21-23, 2005, Belgium.

Shabani, B. (2013). The effect of background knowledge on speaking ability of Iranian EFL learners. International SAMANM Journal of Marketing and Management, 1(1), 222-233.

Skardal, I. (2015). Using pre-speaking activities to increase pupils' oral confidence in English. M.A. Thesis. Norges Arktiske Universitet.

Soto-Santiago, S. L., Rivera, R. L., \& Mazak, C. M. (2015). Con confianza: The emergence of the zone of proximal development in a university ESL course. HOW, 22(1), 10-25. https://files.eric.ed.gov/fulltext/EJ1127936.pdf

Soureshjani, K. H., \& Riahipour, P. (2012). Demotivating factors on English speaking skill: A study of English language learners and teachers' attitudes. World Applied Sciences Journal, 17(3), 327-339. https://pdfs.semanticscholar.org/0d96/6c599fcc295d5833b7b6aebfab0e419057f2.pdf

Thornbury, S. (2007). How to teach speaking. Essex: Pearson Education.

Tsiplakides, I. (2009). Helping students overcome foreign language speaking anxiety in the English classroom: Theoretical issues and practical recommendations. International Education Studies, 2(4), 39-44. doi:10.5539/ies.v2n4p39

Tutyandari, C. (2005). Breaking the silence of the students in an English language class. Paper presented at the $53^{\text {rd }}$ TEFLIN International conference, Yogyakarta, Indonesia.

Ur, P. (1996). A course in language teaching. Cambridge: CUP.

Zare Behtash, E., Saed, A., \& Zare Behtash, P. (2017). The effect of role-playing tasks on the speaking ability of Iranian pre-intermediate ESP Learners. Iranian Journal of English for Academic Purposes, 6(2), 23-32. journalscmu.sinaweb.net/article 73310.html

Ziafar, M., Toughiry, N., \& Sadat Havaeji, Z. (2014). The relationship between teaching conversation through roleplay and the students' speaking development. IJLLALW, 5(1), 547-553. 